\title{
MARTIN LUTHER'S PASTORAL CARE FOR CHRISTIANS ATTACKED BY DEVIL DISGUISED AS AN ANGEL OF LIGHT*
}

\section{Carolyn Schneider**}

\begin{abstract}
Abstrak: Serangan Iblis yang paling berbahaya bagi umat Kristen adalah mematahkan iman dengan membangkitkan keputusasaan dan menanamkan perasaan tidak layak di hadapan Tuhan. Iblis yang menyamar sebagai malaikat terang itu menyerang hati nurani umat Kristen dalam "kesedihan spiritual" (seperti yang pernah dirasakan Martin Luther). Untuk menghadapi serangan iblis ini, pastoral care Martin Luther sangat berguna bagi pertahanan rohani umat Kristen. Firman Tuhan dalam Yesus Kristus adalah satusatunya kekuatan untuk melawan serangan iblis. Untuk itu, umat Kristen harus menjaga intimasi dengan Tuhan baik dalam iman, doa dan komunitas umat percaya lainnya.
\end{abstract}

Kata-kata Kunci: Martin Luther, pelayanan pastoral, iblis, firman Tuhan.

\section{Introduction}

Few Christian theologians have written as much as the sixteenth-century German reformer Martin Luther did, and even

* Paper ini telah disampaikan pada Kuliah Umum tanggal 9 April 2018 di Sekolah Tinggi Teologi Amanat Agung.

** Penulis adalah dosen Sejarah Gereja dan anggota asosiasi Profesor di Lutheran Theological Seminary, Hongkong. 
fewer Christian theologians have written as much about the devil as Martin Luther did. Luther took the devil so seriously that in his famous hymn, "A Mighty Fortress is Our God," he pictures the devil as the prince of this world, calling the devil "the cruel oppressor" and "the old evil foe," who has "sworn to work us woe. With dread craft and might he arms himself to fight. On earth he has no equal. No strength of ours can match his might." ${ }^{1}$

For Luther the most dangerous of the devil's shapes was the "angel of light" against whom Paul warned in 2 Corinthians 11:14 when he said, "Even Satan disguises himself as an angel of light." The angel of light is the devil disguised as righteousness, whom Luther called "the bright, light devil, who does not trouble us with crude sins but with unbelief, because if he has knocked faith over, he has won."2 The angel of light does not tempt people to lust, greed, aggression, or pride, but rather to despair, out of fear that they are unloved by and unlovable to God. This holy devil attacks the conscience and demands human sacrifice, either of endless self-effort or of endless repentance. Those who believe and obey the bright devil think they are fearing and honoring God. This throws a person into the struggle of faith that Luther calls Anfechtung, a temptation to despair,

1. "A Mighty Fortress Is Our God." Hymn \#503, in Evangelical Lutheran Worship (Minneapolis: Augsburg Fortress, 2006).

2. Luther, quoted in Hermannus Obendiek, Der Teufel bei Martin Luther: Eine theologische Untersuchung, Furche-Studien, ed. Fritz Blanke et al. (Berlin: Furche-Verlag, 1931), 144, my translation. 
"spiritual sadness," or "melancholy." Luther experienced this often himself and said that it once even led him to the brink of suicide. ${ }^{3}$

In the Middle Ages there was no doubt that the devil was real and could affect one's thoughts, heart, and mind. For many people in the world today that is still the case, and Luther's talk of the devil needs no translation. But others find his realistic sense of the devil strange. The troubles that Luther ascribed to the devil, such as illness and suicidal thoughts, are now dealt with in medical or psychological terms. Yet it is an inescapable fact that the Bible, and the New Testament in particular, presents the devil as a real force to be reckoned with.

In an influential series of books called The Powers, Walter Wink provides a helpful way for post-Enlightenment people to think about this biblical devil in terms of an integrated worldview, in which everything has an inner and an outer side, an invisible as well as a visible dimension. He associates the spiritual, invisible dimension of reality with the biblical "powers" described most fully in Ephesians 6:10-12, which urges the hearers to

be strong in the Lord and in the strength of his power. Put on the whole armor of God, so that you may be able to stand against the wiles of the devil. For our struggle is not against enemies of blood and flesh, but against the rulers, against the

3. Jacques Ridé, "Diable et Diableries dans les Propos de Table de Martin Luther," in Diable, Diables et Diableries au Temps de la Renaissance, ed. M.T. Jones-Davies, Université de Paris-Sorbonne Societe Internationale de Recherches Interdisciplinaires sur la Renaissance (Paris: Jean Touzot Libraire-Editeur, 1988), 118-19. 
authorities, against the cosmic powers of this present darkness, against the spiritual forces of evil in the heavenly places.

Wink calls this army of invisible powers, led by the devil, not a "physical phenomenon" but a "spiritual construct" of evil "born of words" and ideas. ${ }^{4}$ It is the web of lies, ideologies, or "isms" that we believe and through which we interpret the world so that we have false images of ourselves, others, and God. Wink suggests that Ephesians 6:17 is right when it says that the only thing that can cut through this web of lies is "the sword of the Spirit, which is the word of God."

Martin Luther could not agree more, in spite of his differing perception of the devil as a personal being. In the final verse of "A Mighty Fortress" he sings that "one little word subdues (this world's tyrant). God's Word forever shall abide, no thanks to foes, who fear it; for God himself fights by our side with weapons of the Spirit." By "God's Word" Luther means primarily the Word who "became flesh and lived among us, and we have seen his glory, the glory as of a father's only son, full of grace and truth" (John 1:14). As theologian Hendrik Berkhof wrote, the believer's "duty is not to bring the Powers to their knees. This is Jesus Christ's own task ... Our weapon is to stay close by (Christ)." ${ }^{5}$

4. Walter Wink, Naming the Powers: The Language of Power in the New Testament, vol. 1 of The Powers (Philadelphia: Fortress, 1984), 88.

5. Hendrik Berkhof, Christ and the Powers, trans. John H. Yoder (Pennsylvania: Herald, 1977), 52. 
Today we will explore how Luther advised those under attack by Satan as an angel of light to stay close to Christ and how that advice can still be useful in our own time. To do so we will first look at Luther's teaching about the assault of the righteous devil and the Christian's best defense against it. Then we will look at how a young woman of our own time found Luther's teaching helpful in making a theological interpretation of her past struggle with an eating disorder and her recovery from it. It will become clear that because faith unites Christ and the Christian, in the battle against the devil, faith has the power to force Satan to be a servant of God and thus converts the devil's attack from a moment of destruction to a moment of salvation.

\section{Christians as Righteous People and Sinners at the Same Time}

Martin Luther understood Christians to be both fully righteous and fully sinful at the same time. They are fully righteous because they wear the wedding ring of faith that unites them with Christ. By this union, their sins "are laid upon Christ and swallowed up by him," Luther says, and Christ's own righteousness is given to them in return. ${ }^{6}$ Thus, since Satan, whose name means "Accuser," no longer has any claim or power over the resurrected Christ, then Satan no longer has any claim or power over Christians either, who have been pulled out of their "own skin, and transferred into Christ and into His kingdom, which is a kingdom of grace, righteousness, peace,

6. The Freedom of a Christian, LW 31:352/WA 7:55. 
joy, life, salvation, and eternal glory," as Luther says in his lectures on Galatians. $^{7}$

But when Christians lose hold of faith, then they are left with themselves alone and their own sinfulness. In his role as Satan the devil can still claim the right of accusation over Christians insofar as they are still sinners; this authority has been given to the devil by God. Satan is never equal to or independent of God in Luther's eyes. Rather, Luther sees the devil as God's tool, as if God had seized the devil and said, "Devil, you are indeed a murderer and an evildoer; but I will use you for my purpose." ${ }^{8}$ By unveiling the sin of Christians the devil means to lead Christian people to despair and to destroy them entirely. But God's purpose in unveiling sin is to lead Christian people to repentance and conversion, driving them back to Christ through the preaching of the gospel, in which they can see their old self with its sin, guilt, will, and reason, put to death in Christ and a new self raised up with Christ. God's purpose with the devil is to strengthen faith and confidence in God alone when believers appropriate to themselves Christ's life, through his suffering, death, hell, resurrection, ascension, and seat at God's right hand. By this faith they have victory over both sin and the devil.

Therefore, the devil knows that the only way to kill Christians is to undermine their faith. The shield of faith is Christians' strongest

7. Lectures on Galatians (1535), LW 26:167/WA 40 I:284.

8. Sermons on the Gospel of St. John, LW 24:195/WA 45:638. 
weapon because it deflects the devil away from themselves and forces the devil to take up the fight with Christ, who has already defeated him. Thus, the devil must disarm Christians of faith in order to destroy them.

Luther retained medieval tradition when he understood the soul's bridal union with Christ to be not only the shield against the devil's attacks but also sometimes the reason for these attacks. Medieval historian Nancy Caciola writes that in the Middle Ages, "demonic attack often was represented by penitents themselves as a direct result of their closeness to God. The devil ... made particular efforts to assault the special friends of God, either in the hope of making them backslide or simply out of hatred." ${ }^{9}$ Thus, the more firmly Christians clung to Christ the more certain they might be that they were the devil's targets. ${ }^{10}$ As Jesus told the medieval nun Mechthild of Hackeborn (1241-1299) in a vision, "Do not be surprised if thoughts bother you, even when you are in my presence, since the devil also tempted me when I began the work of salvation for you." 11

9. Nancy Caciola, Discerning Spirits: Divine and Demonic Possession in the Middle Ages, Conjunctions of Religion \& Power in the Medieval Past, ed. Barbara H. Rosenwein (Ithaca: Cornell University, 2003), 70-71.

10. Bengt Hoffman, Theology of the Heart: The Role of Mysticism in the Theology of Martin Luther, ed. Pearl Willemssen Hoffman (Minneapolis: Kirk House, 1998), 229.

11. Mechthild von Hackeborn, Buch besonderer Gnade, vol.1 of Leben und Offenbarungen der heiligen Mechtildis und der Schwester Mechtildis (von Magdeburg), Jungfrauen aus dem Orden des heiligen Benediktus, ed. J. Müller (Regensburg: G.J. Manz, 1880), 163 (Book II, chap. 12). 
Satan is no fool, as Luther presents him. Satan realizes that this temptation to lose trust in God must be very subtle so that Christians do not recognize what is happening to them. In analyzing Satan's strategy, Luther saw the attack taking place in stages. In the first stage of the assault Satan ever so gently uses particular scriptures or words of God to suggest to a person's heart the possibility that God's intentions toward him or her are not clear. For example, in his lectures on Galatians, Luther puts these words in Satan's mouth: "Of course, Christ is gentle, kind, etc., but only to those who are righteous and holy. By contrast, He threatens sinners with wrath and perdition (Luke 13:27-28) and declares that unbelievers are already condemned (John 3:18)." ${ }^{12}$ The angel of light knows the scriptures very well. Then the second stage of the assault begins with the righteous devil in the role of God's prosecuting attorney. The Accuser points out to the conscience all the reasons that God would have to reject one, all of one's sins. Luther told his students that the devil even "knows how to inflate a minute and almost ridiculous peccadillo until the one who has been tempted supposes it to be the most heinous offense, worthy of eternal punishment." ${ }^{\prime 3}$ And not only that; in his lectures on 1 John, Luther says that Satan is also "a skilled artisan of fictitious sins which are not sins." He "fashions sins" with which to accuse us "so that we might 
be terrified by them." ${ }^{14}$ Through Satan's urging Christians can no longer see Christ as a "merciful Savior and Comforter,"15 but they come to have a false image of Christ as their Accuser. In this way Satan, the Accuser, replaces Christ with himself in the Christians' consciences.

\section{Brandi's Story}

This process is exactly what happened to my student Brandi, who has given me permission to share her story. She said, "It would bring me joy to know it is being used by someone." Brandi had been a devout teenager and wanted to live by what she thought were God's standards so that she could make God look good in the world. She knew from 1 Corinthians 6:19 that her body was "a temple of the Holy Spirit" and that she should take care of it. She found clear instructions for how to treat her body in the pages of "Vogue" and "Shape" magazines. These sources informed her that the standard was to be a very thin one meter and seventy centimeters tall, weighing 45 kilograms. Brandi soon achieved the weight goal but it was not enough. She strove for more and more weight loss as she became overwhelmed by feelings of "inadequacy, ... self-hatred, ... worthlessness and despair."16 Ironically, what Brandi began as an

14. Vorlesung über den 1. Johannesbrief (1527), WA 20:767.

15. Lectures on Galatians (1535), LW 27: 34/WA 40 II:42.

16. Brandi Duble, "Shrinking before Grace: Proclaiming the Gospel to a Girl Suffering with an Eating Disorder," Senior Seminar Paper, Texas Lutheran University, Seguin, April 2003, 7-8. 
attempt to glorify God became for her idolization of commercialism, which loves no one. Commercialism has the voice that tradition calls Satan, the liar who even makes sins out of things that "are not actually sinful," such as eating normally. ${ }^{17}$ The images Brandi internalized from our consumerist society formed what Luther called a "false picture" that functioned as an "image of condemnation" and prevented her from developing a strong, real, integrated, healthy self. ${ }^{18}$

Looking back on the experience, Brandi wrote a paper about proclaiming the gospel to a girl suffering from an eating disorder. In her research she was struck by a passage in one of Martin Luther's sermons, where he wrote, "What happens in the conscience is this: When God comes with his grace, ... the devil strikes a blow too. He magnifies $\sin$ in the heart to such a degree that you are unable to see anything but your unworthiness, and you must, therefore, shrink in terror before great and boundless grace." ${ }^{19}$ What struck Brandi in this passage was the shrinking because, she said, a "girl suffering with an eating disorder literally shrinks her body before she realizes Grace is meant for her." 20

17. Duble, "Shrinking before Grace," 12.

18. Bruce Parmenter, "Devil Talk': A Case History of Martin Luther's Pastoral Counseling with 'Herr Turbicide,' Compared to a 'Modern' Case of Depression," American Journal of Pastoral Counseling 7 no. 1 (2003): 56.

19. Eugene F.A. Klug, ed., Fifth Sunday after Trinity, Second Sermon, vol. 2 of Sermons of Martin Luther: The House Postils (Grand Rapids: Baker, 1996), 298.

20. Duble, "Shrinking before Grace," 12. 
Brandi was helped by a friend who had gone through a similar experience and who had sought counseling. This friend was able to show her how her behavior was not in fact making her body fit as the temple of the Holy Spirit, but was harming it instead. Once Brandi was able to see this real sin instead of the false sin, she was also able to find "comfort and confidence in the Gospel," which told her that "the Lord declares her righteous through Christ even though she is still considered a sinner through humans." ${ }^{21}$ Now she is formed by a new image and sees herself as a daughter of God. Luther called this an "image of grace" because in the risen Christ, he preaches in an Easter sermon, ${ }^{22}$

there is no sin, no curse, no disfavor, no death anymore, but plain life, grace, bliss, and righteousness. With such an image we should raise up our hearts because it is placed in front of us and given to us so that we might see ourselves in no other way than as if God had raised us ourselves with Christ today. For as little as you see sin, death, and curse in Christ, you should believe that God also wants to see just as little [of these] in you for the sake of Christ, when you take his resurrection to yourself and find comfort in it.

This image of grace changed Brandi's vision of herself. But not only that. The image of the risen Christ is so powerful that when one embraces it as an image of oneself even God's vision of a person is

21. Duble, "Shrinking before Grace," 15-16.

22. Am heiligen Ostertag, von frucht der Aufferstehung Christi. Euangelion Math. xxviii, in Hauspostille 1544, WA 52:250-51. 
transformed and God, too, sees the faithful person as someone full of Christ's righteousness. So, ultimately, the devil did not succeed in overthrowing Brandi's faith and destroying her.

The new life of a Christian does not require the destruction of the body, either at one's own hands or at the hands of others. As Luther wrote to Prince Joachim of Anhalt, who was suffering from depression, God "does not desire a gloomy sacrifice," but wants us to live. "Be merry, then, both inwardly in Christ himself and outwardly in his gifts and the good things of life," Luther told him. ${ }^{23}$

Luther knew that the devil tried to cause people to lose heart and question their worth. To those who questioned whether they were "worthy of God's attention," Luther wrote a "short note of comfort" advising them to remember this: ${ }^{24}$

1. I was worth God my Creator creating me out of nothing and forming me in my mother's womb, etc.

2. I was worth God redeeming me through his onlybegotten Son's death and precious blood.

3. I was deemed worth the Holy Spirit's teaching me of Christ, the Son of God, and his giving my heart delight in and love of the Gospel.

23. WABr 7:67, in Theodore Tappert, ed. Luther: Letters of Spiritual Counsel, Library of Christian Classics, ed. John Baillie, John T. McNeill, and Henry P. Van Dusen, no. 18 (Philadelphia: Westminster, 1955), 93.

24. WA 51:455-456, translated and discussed in M.E. Schild, "Praying the Catechism and Defrocking the Devil - Aspects of Luther's Spirituality," Lutheran Theological Journal 10 no. 2 (August, 1976): 50. 
According to church historian Jane Strohl, when the angel of light comes and says to us in God's voice, "You are not worthy of my grace; I will change My plan and not keep My promise to you," Luther asserts that faith's "proper response is not, 'Oh please, I beg of you; don't do that' but 'Too late, I have your promise'." ${ }^{25}$ Luther believed that God puts even the devil to work to train and strengthen the faith of God's beloved in order to make them bold, not timid.

\section{Conclusion}

In The Freedom of a Christian, Luther calls faith the "absorbing of the Word," which "communicate[s] to the soul all things that belong to the Word." 26 Those who identify themselves with Christ by faith share his victory. "Thus," as Luther scholar Simo Peura puts it, "redemption is something that happens not only on the cross but also in all believers whom Christ indwells through faith." ${ }^{27}$

Luther recognized that, in his words, "the devil occasionally assails the pious Christian hearts so hard with his fiery darts (Eph. $6: 16)$ that they not only become oblivious to the exuberant glory of their filial relationship to God but also give way to the opposite ideas, as, for instance, that God has forgotten them or forsaken them, or

25. Jane Strohl, "Luther and Endurance" (paper presented at the North American Forum for Luther Research, Concordia Seminary, St. Louis, Missouri, April 18-20, 2008).

26. LW 31:349/WA 7:53.

27. Simo Peura, "What God Gives Man Receives: Luther on Salvation," in Union with Christ: The New Finnish Interpretation of Luther, ed. Carl E. Braaten and Robert W. Jenson (Grand Rapids: Eerdmans, 1998), 90. 
has repudiated them and cast them from his sight." ${ }^{28}$ Yet, as profoundly frightening as these ideas are that the devil stirs up in people, Luther assured his students that they can be used to one's own advantage.

First, faith must convert the devil into a servant of God and must shift the agency of the temptation to despair from Satan to Satan's Lord, as both Job and Jesus did in their time of trial, when Job asks God again and again, "Why are you doing this to me?," and Jesus quotes Psalm 22:1 from the cross, "My God, my God, why have you forsaken me?" It may have been the devil who tempted them to see their suffering as abandonment by God, but they respond by ignoring the devil and talking to God as the one ultimately responsible for their lives. Thus temptation to despair should drive Christians to prayer. In Luther's eyes, this appeal of a faithful person to God in the face of God's apparent rejection overwhelms God so that God overflows with compassion and comes near to save us. ${ }^{29}$ Even if that prayer is no more than a sigh "too deep for words" (Romans 8:26), Luther says, it will "'pierce the clouds' (Ecclus 35:21) and ... compel the Divine Majesty to forgive and to save." ${ }^{30}$

Second, a Christian tempted to despair can seek out another Christian because, as Luther writes, "The Holy Spirit knows that the

28. Sermons of the Gospel of St. John (1537), LW 22:90/WA 46:613.

29. Gerhard Forde, On Being a Theologian of the Cross: Reflections on Luther's Heidelberg Disputation, 1518 (Grand Rapids: Eerdmans, 1997), 88-91.

30. Psalm 90, LW 13:110/WA 40 III:542. 
devil is fully mobilized and that he attempts every hour of the day to assail us with such thoughts of despair and rejection. Therefore the Spirit reminds and admonishes us everywhere that Christians have authorization from God Himself to teach and console one another." ${ }^{31}$ It was with the help of a friend that Brandi was rescued. A student of Luther's recorded a dinner conversation in which Luther modeled such consolation for his troubled friend Johann Feldkirch. Luther reminded Feldkirch that the devil was attacking him precisely because he had so far resisted the devil and still belonged to Christ, so he should say to himself, "The devil may be angry about it and make me sad, but my victory stands, because Christ lives." Luther assured him that he was not in this struggle alone because not only was God with him but so was the Christian community. Luther told him, "[W]e together with you belong to the body redeemed by the blood of Christ, washed in the blood of Christ and then joined by word and sacrament to the society of the church. ... Don't let the devil in the room. Say, 'You may not enter here. Here the Lord Jesus will reign, in whom I am baptized'." ${ }^{32}$

To sum up, for Luther, the power to combat the angel of light is the Word of God deep in the wounded but risen body of Jesus, by which God has made a pledge of salvation to humans with God's own life. This incarnate Word of God gives them the necessary basis to

31. Psalm 90, LW 13:111/WA 40 III: 543.

32. Tischreden aus den dreißiger Jahren, \#3669, WATr 3:507. 
counter the suggestions of the angel of light that would strip them of their relation to God as God's children. Those who cling to Christ by faith are carried in Christ beyond sin, accusation, guilt and condemnation. This is how they are rescued from the angel of light and his temptation to despair.

\section{Bibliogrphy}

Berkhof, Hendrik. Christ and the Powers. Translated by John H. Yoder. Pennsylvania: Herald, 1977.

Caciola, Nancy. Discerning Spirits: Divine and Demonic Possession in the Middle Ages. Conjunctions of Religions \& Power in the Medieval past. Edited by Barbara H. Rosenwein. Ithaca: Cornell University, 2003.

Duble, Brandi. "Shrinking before Grace: Proclaiming the Gospel to a Girl Suffering with an Eating Disorder." Senior Seminar Paper. Texas Lutheran University: Seguin, 2003.

Forde, Gerhard. On Being a Theologian of the Cross: Reflections on Luther's Heidelberg Disputation, 1518. Grand Rapids: Eerdmans, 1997.

Hackeborn, Mechthild von. Buch besonderer Gnade. vol. 1 of Leben und Offenbarungen der heiligen Mechtildis und der Schwester Mechtildis (von Magdeburg), Jungfrauen aus dem Orden des heiligen Benediktus. Edited by J. Müller. Regensburg: G.J. Manz, 1880.

Hoffman, Bengt. Theology of the Heart: The Role of Mysticism in the Theology of Martin Luther. Edited by Pearl Willemssen Hoffman. Minneapolis: Kirk House, 1998.

Luther, Martin. D. Martin Luthers Werke. Kritische Gesamtausgabe. 73 vols. Weimar: Hermann Böhlaus Nachfolger, 1883-2009. . D. Martin Luthers Werke. Kritische Gesamtausgabe. Tischreden. 6 vols. Weimar: Hermann Böhlaus Nachfolger, 1912-21. 
. Luther's Works. Edited by Jaroslav Pelikan, Helmut T. Lehmann, and Christopher Boyd Brown. 78 vols. Philadelphia: Fortress; St. Louis: Concordia, 1955 - .

"A Mighty Fortress Is Our God." Hymn \#503 in Evangelical Lutheran Worship. Minneapolis: Augsburg Fortress, 2006.

Parmenter, Bruce. "'Devil Talk': A Case History of Martin Luther's Pastoral Counseling with 'Herr Turbicide,' Compared to a 'Modern' Case of Depression," American Journal of Pastoral Counseling 7 no. 1 (2003): 67-72.

Peura, Simo. "What God Gives Man Receives: Luther on Salvation." In Union with Christ: The New Finnish Interpretation of Luther. Edited by Carl E. Braaten and Robert W. Jenson. Grand Rapids: Eerdmans, 1998.

Ridé, Jacques. "Diable et Diableries dans les Propos de Table de Martin Luther." In Diable, Diables et Diableries au Temps de la Renaissance. Edited by J.T. Jones-Davies. Université de Paris-Sorbonne Societé Internationale de Recherches Interdisciplinaires sur la Renaissance. Centre de Recherche sur la Renaissance 13. Paris: Jean Touzot Libraire-Editeur, 1988.

Strohl, Jane. "Luther and Endurance." Paper presented at the North American Forum for Luther Research, Concordia Seminary, St. Louis, Missouri, April 18-20, 2008.

Tappert, Theodore, ed. Luther: Letters of Spiritual Counsel. Library of Christian Classics, edited by John Baillie, John T. McNeill, and Henry P. Van Dusen, no. 18. Philadelphia: Westminster, 1955.

Wink, Walter. Naming the Powers: The Language of Power in the New Testament. vol. 1 of The Powers. Philadelphia: Fortress, 1984.

\section{Abbreviations}

LW = Luther, Martin. Luther's Works. Edited by Jaroslav Pelikan, Helmut T. Lehmann, and Christopher Boyd Brown. 78 vols. Philadelphia: Fortress; St. Louis: Concordia, 1955 - . 
WA = Luther, Martin. D. Martin Luthers Werke. Kritische Gesamtausgabe. 73 vols. Weimar: Hermann Böhlaus Nachfolger, 1883-2009.

WATr = Luther, Martin. D. Martin Luthers Werke. Kritische Gesamtausgabe. Tischreden. 6 vols. Weimar: Hermann Böhlaus Nachfolger, 1912-21. 